Article

\title{
The Impacts of the Perceived Golf Course Brand Globalness on Customer Loyalty through Multidimensional Perceived Values
}

\author{
Woo-yeul Baek ${ }^{1}$, Kyungyeol (Anthony) Kim ${ }^{2}$, Doo-Han Kim ${ }^{3, *}$ and Kevin K. Byon ${ }^{2}$ \\ 1 Department of Sport Management, Kyonggi University, Suwon 154-42, Korea; wyb71@kyonggi.ac.kr \\ 2 Department of Kinesiology, Indiana University-Bloomington, Bloomington, IN 47405, USA; \\ kk39@indiana.edu (K.A.K.); kbyon@indiana.edu (K.K.B.) \\ 3 Department of Taekwondo, Korea National Sport University, Seoul 1239, Korea \\ * Correspondence: doo21han@knsu.ac.kr
}

Received: 2 January 2020; Accepted: 25 January 2020; Published: 29 January 2020

check for updates

\begin{abstract}
The purpose of the present study is to investigate the relationships among brand globalness, perceived values (i.e., functional, emotional, social, and altruistic values), and customer loyalty in the context of Korean professional golf tournaments. Data were collected from spectators $(n=198)$ of two golf tournaments organized by the Ladies Professional Golf Association (LPGA). The results showed that golf course brand globalness positively influenced perceived value (i.e., functional, emotional, social, and altruistic). Perceived value (i.e., functional, emotional, and social) was found to be related to customer loyalty. We also found a mediating effect of perceived value (i.e., functional, emotional, and social) on the relationship between golf course brand globalness and customer loyalty. Theoretical and managerial implications along with suggestions for future research are discussed.
\end{abstract}

Keywords: golf course; brand globalness; perceived value; customer loyalty

\section{Introduction}

Customer satisfaction has long been an interest in marketing research, as it is believed to help organizations secure a loyal customer base [1]. It has been suggested that higher customer satisfaction increases customer loyalty across a variety of service and product industries [2]. In particular, dissatisfied customers may complain or leave to competitor brands, but increasing overall customer satisfaction may reduce complaints and increase customer loyalty. However, due to the increased competition among sport organizations and diversified consumption experiences of customers, high levels of purchase satisfaction may not be linked to actual repurchase behavior [3]. More than 60 percent of customers who showed high satisfaction reported that they would switch to competitors that offer better customer value [3]. As such, in a today's highly competitive market environment, it is difficult for organizations to create a sustainable competitive advantage by simply providing customer satisfaction.

Recently, research on customers' perceived value has provided sport organizations with effective marketing strategies to secure and maintain loyal customers $[4,5]$. For example, Jones, Byon, and Huang [6] examined how service quality factors (i.e., interaction and physical environmental qualities) influenced utilitarian and hedonic values, which in turn affected customer engagement behavior in the context of Shanghai Formula One racing. Likewise, previous scholars reported several antecedents of customers' perceived value, such as service quality [4,6,7], team identification [8], other customers' behaviors [9], and emotional consumption experiences [10]. Furthermore, scholars found that perceived value embedded in service has a positive impact on improving customer satisfaction [11], brand image [7], and customer loyalty, which includes repurchase and word-of-mouth intention [9]. 
Researchers have also suggested that brand globalness, which is defined as the levels of customers' belief that a certain brand is available in the global markets [12], can be a significant predictor of customers' perceptions of brand value and behavioral intention. In particular, because customers' interests in environmental and social issues are considered meaningful consumption value, consumers' perceived brand globalness for a particular brand is reported to be associated with the customers' positive perceptions of the brand's social responsibility and the functional value that represents quality excellence [13]. This is because with the advancement of communication technologies and the mitigation of trade barriers among countries, customers around the world can share similar consumption desires and tendencies [14,15]. However, previous studies have not examined how brand globalness influences customer loyalty mediated by customers' perceived value in the context of spectator sport.

Golf spectatorship has seen a growth in profits [16]. Particularly, the popularity of Korean professional golf spectatorship has continuously grown [17]. For example, there are more than 500 golf courses, and golf is the most participated sport in South Korea [17]. Although the Korean golf course industry has firmly established itself as an important part of the sport service industry, it is facing an increased domestic competition with other service industries. Therefore, Korean golf course organizations have made efforts to implement a global strategy. For example, the Sky72 Golf Course has held an annual golf tournament, the Ladies Professional Golf Association (LPGA) Korea Exchange Bank (KEB) Hana Bank Championship, since 2008 to achieve a brand positioning strategy and to enhance the global brand image. Consistent with the Korean golf industry's trend, it is appropriate to shed light on customers' perceived brand globalness in the context of Korean golf courses.

In sum, we investigated the relationships among customers' perceived brand globalness, multidimensional perceived value including functional, emotional, social, and altruistic values, and customer loyalty in the context of the Korean golf course industry. The findings from the current study provide guidelines for golf course managers seeking a sustainable competitive advantage through brand globalness and brand value proposition.

\section{Theoretical Background and Hypothesis Development}

\subsection{Brand Globalness}

Brand globalness refers to the degree of customers' perceptions of the availability of a product or service in global markets [12]. Brand globalness serves to measure how global a brand is perceived to be [12]. Customers' perceived brand globalness can be first created such that customers perceive that a certain brand is available in both global and local markets through various channels, such as overseas traveling, international sports broadcasting, and social media. Even if a brand does not exist in global markets, customers' perceived brand globalness can be formed by companies' marketing communication efforts, such as advertisements and positioning strategies as global brands. These activities, in turn, are likely to influence customers' perceptions of organizations as valuable global brands [18]. In a comparative study of global and local brands, Davvetas, Sichtmann, and Diamantopoulos [19] found that customers are willing to pay more for global brands than local ones, indicating the advantage of brand globalness. Therefore, the brand globalness of a particular product or service is an end-product of the interaction between companies' global positioning activities and customers' awareness.

\subsection{Perceived Value}

Customers' perceived value that an organization provides to its customers is recognized as a top priority for the organization to enhance a sustainable competitive advantage in a market [20]. Perceived value refers to customers' overall assessments of a purchased product or service through the interaction between benefits and sacrifices based on the perceptions of what consumers have acquired and abandoned through purchasing behavior [20]. However, this view limits the interpretation and 
prediction of customer behaviors by defining perceived value as a single dimension created by a trade-off between product quality and cost [21]. That is, prior scholars using the unidimensional perceived value do not properly reflect the multidimensionality of perceived value, such as functional, emotional, social, and altruistic values suggested by existing studies on customer value $[20,21]$.

To overcome the limitations of the single-dimensional value concept, Sweeney and Soutar [22] suggest the concept of multidimensional perceived value such as emotional, social, functional, and monetary values. Similarly, Steenkamp and Geyskens [10] reported that customers' evaluations on the product value consist of four distinctive elements, namely, functional, emotional, quality, and price values. The authors argued that customers assess value not just in terms of expected performance and cost-effectiveness, but also about the enjoyment of purchasing a product and social consequences. Holbrook [23] identified four distinctive components of perceived value, namely, intrinsic, extrinsic, self-oriented, and other-oriented values. In particular, from the perspective of corporate social responsibility activities that emphasize sound corporate citizenship of a firm, altruistic value has become more important than ever, along with the firm's traditional profit-generating activities [24]. Therefore, customers' perceived value should be theorized as multidimensional aspects including functional value, which satisfies customers' demand for relative product performance compared to price, emotional value about happiness and enjoyment, social value, which is related to how customers interact with other customers, and altruistic value, which intends to meet customers' desire for social contributions with their purchasing behavior.

\subsection{Brand Globalness and Perceived Value}

Perceived value can be shaped by a variety of factors. For example, in the context of a spectator sport, customers' perceived value can be created by service quality [4], team identification [8], and other customer behaviors (i.e., passion and dysfunctional behavior) [9]. It has also been suggested that brand globalness can be an important antecedent of customers' perceived value. For example, Swoboda, Pennemann, and Taube [15] found that brand globalness was positively related to functional value, which represented a value assessment of product quality, and emotional value, composed of enjoyment and happiness derived from purchasing a product. Zhou, Yang, and Hui [14] also reported that when customers perceived a brand as a foreign image, they were likely to show higher levels of perceptions of social value. In a study investigating the relationship between customers' perceived brand globalness and product quality, Steenkamp, Batra, and Alden [12] found that customers tended to rate a particular brand's reputation highly if they perceived the brand as a global image. Additionally, Baek, Byon, Choi, and Park [24] reported that customers' perceptions of the brand globalness of a sportswear brand positively influenced customers' evaluations on the company's corporate social responsibility campaign, recognizing the importance of the social value that the company offers. Thus, we proposed the following hypotheses:

Hypothesis 1. Perceived golf course brand globalness will have a positive effect on functional value.

Hypothesis 2. Perceived golf course brand globalness will have a positive effect on emotional value.

Hypothesis 3. Perceived golf course brand globalness will have a positive effect on social value.

Hypothesis 4. Perceived golf course brand globalness will have a positive effect on altruistic value.

\subsection{Brand Globalness and Perceived Value as Antecedents of Customer Loyalty}

Customer loyalty is a state of immersion in which customers tend to re-engage with a product or service in the form of repurchase or reuse, regardless of other available competitors' products and services. Therefore, customer loyalty leads to increased purchase frequency and quantity, favorable word-of-mouth, and ultimately reduced marketing costs [25]. 
Several factors can be identified as predictors for loyalty formation. For example, previous studies show that product quality, customer satisfaction, and brand image are strong predictors of customer loyalty e.g., [7,11]. Steenkamp et al. [12] reported that perceived brand globalness has a direct impact on perceived quality and brand reputation, which in turn positively affects purchase intention. Similarly, Pyun, Kwon, and Lee [26] reported that Korean television viewers' perceived brand globalness of the English Premier League (EPL) has a positive influence on their viewing intention for EPL soccer games. Thus, we developed the following hypothesis:

Hypothesis 5. Perceived golf course brand globalness will have a positive effect on customer loyalty.

The multidimensional customers' perceived value includes functional, emotional, social, and altruistic values. These factors are expected to affect customer loyalty positively. For example, Roig, Barcia, and Tena [11] found that customers' positive assessments of overall service quality positively predicted revisit intention. Similarly, Moliner, Sanchez, Rodriguez, and Callarisa [27] found that emotional value and functional value positively influenced repurchase intention and favorable word-of-mouth intention. In the Korean golf tournament context, social value positively predicted word-of-mouth [9], and positive social interaction among customers positively affected customer citizenship behavior (i.e., helping other customers and word-of-mouth) [28]. Baek et al. [24] also reported that customers who were highly aware of the brand globalness of a sporting goods firm positively assessed the company's intention to carry out a corporate social responsibility campaign and ultimately expressed their willingness to purchase products. Thus, we proposed the following hypotheses (see Figure 1 for the proposed model):

Hypothesis 6. Functional value will have a positive effect on customer loyalty toward a golf course brand.

Hypothesis 7. Emotional value will have a positive effect on customer loyalty toward a golf course brand.

Hypothesis 8. Social value will have a positive effect on customer loyalty toward a golf course brand.

Hypothesis 9. Altruistic value will have a positive effect on customer loyalty toward a golf course brand.

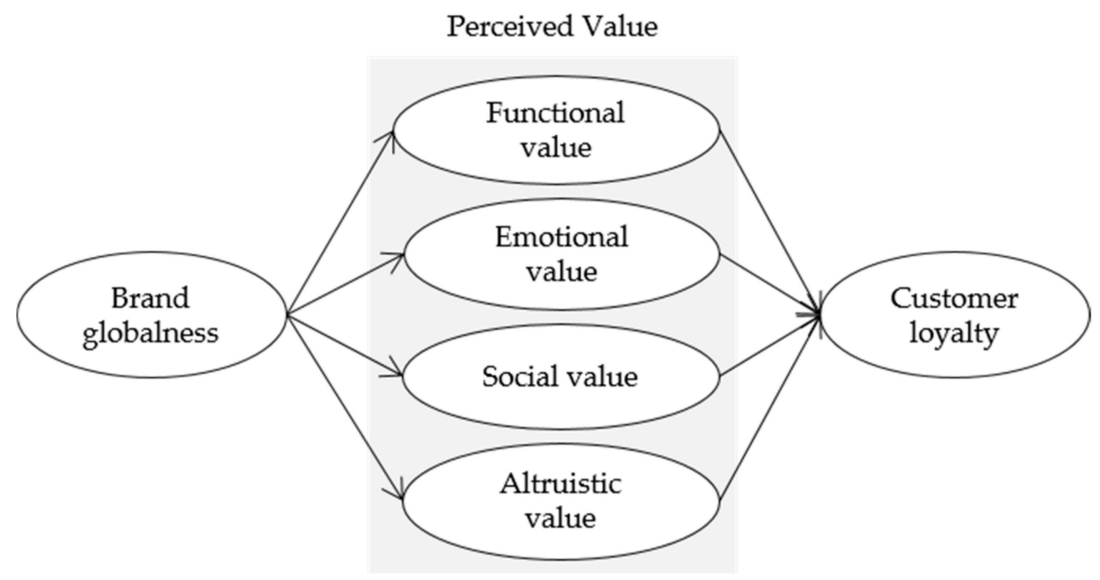

Figure 1. Proposed model.

\section{Method}

\subsection{Research Setting}

To understand how golf course brand globalness has an impact on customer loyalty through perceived values, professional golf tournaments were chosen as a research context. According to Sirak and Waraksa [29], the Augusta National Golf Course in Georgia in the U.S., where the Masters 
Tournament is held, generated about $\$ 115$ million in revenue in 2015 , which was more than a five-fold increase compared to $\$ 22$ million in 1997. Along with revenue generation from hosting an internationally well-known golf tournament, customers' brand value perceptions of the golf course as a global brand through both domestic and international television broadcasting have had a great impact on creating a sustainable competitive advantage. The Augusta National Golf Course is considered to be one of the must-visit golf courses for many spectators around the world [30].

In the current study, we chose LPGA tournaments as an appropriate research setting because the LPGA is an internationally well-known non-profit organization. Furthermore, the LPGA is recognized as having a global image and organizes women's golf tournaments around the world, including the U.S., South Korea, and China. Thus, golf customers who visit the target golf courses in the present study would be more likely to develop a certain degree of the global brand image of the golf courses.

\subsection{Participants and Data Collection Procedures}

We collected data from spectators attending one of two LPGA golf tournaments in October 2018. To avoid sampling bias, five trained surveyors spread out on a golf course to collect data from spectators who had finished watching a golf tournament in numerous places, including the $18^{\text {th }}$ hole, parking lots, restaurants, cafes, and souvenir shops [9]. As a screening question, we asked survey respondents to see if they had participated in this survey previously to eliminate any duplicate answers during the data collection. As a result, 200 survey questionnaires were collected, and two questionnaires were excluded because of incomplete responses, leaving 198 usable questionnaires. Male participants accounted for $69.2 \%$, and the majority of participants were in their $40 \mathrm{~s}$ and older $(70.7 \%)$ and college graduates $(83.3 \%)$. Of the respondents, $36.3 \%$ reported monthly incomes of below $\$ 4999$, and 36.3\% stated that their frequency of annual golf attendance was two times. Table 1 reports the summary of demographics.

Table 1. Participant demographics.

\begin{tabular}{|c|c|c|c|c|c|}
\hline Variables & Categories & Frequency (\%) & Variables & Categories & Frequency $(\%)$ \\
\hline \multirow[t]{4}{*}{ Gender } & Male & $137(69.2 \%)$ & \multirow{4}{*}{$\begin{array}{l}\text { Frequency of } \\
\text { annual } \\
\text { attendance }\end{array}$} & 1 time & $29(14.6 \%)$ \\
\hline & Female & $61(30.8 \%)$ & & 2 times & $43(21.7 \%)$ \\
\hline & & & & 3 times & $32(16.2 \%)$ \\
\hline & & & & 4 times & $26(13.2 \%)$ \\
\hline \multirow[t]{6}{*}{ Age } & Below 20 & $10(5.1 \%)$ & & More than 5 times & $68(34.3 \%)$ \\
\hline & $20-29$ & $29(14.6 \%)$ & \multirow{5}{*}{ Occupation } & & \\
\hline & $30-39$ & $19(9.6 \%)$ & & Student & $28(14.1 \%)$ \\
\hline & $40-49$ & $67(33.8 \%)$ & & Self-employed & $61(30.8 \%)$ \\
\hline & $50+$ & $73(36.9 \%)$ & & Government officer & $14(7.1 \%)$ \\
\hline & & & & Office worker & $55(27.8 \%)$ \\
\hline \multirow[t]{5}{*}{ Education } & High school & $24(12.1 \%)$ & & Housewife & $30(15.2 \%)$ \\
\hline & College student & $9(4.5 \%)$ & & Others & $10(5.0 \%)$ \\
\hline & College graduate & $143(72.2 \%)$ & & & \\
\hline & Advanced degree & $22(11.2 \%)$ & \multirow{6}{*}{$\begin{array}{l}\text { Years of golf } \\
\text { experience }\end{array}$} & Below 1 year & $20(10.1 \%)$ \\
\hline & & & & $1-3$ years & $33(16.7 \%)$ \\
\hline & Below $\$ 2999$ & $41(20.7 \%)$ & & $3-5$ years & $63(31.8 \%)$ \\
\hline \multirow[t]{3}{*}{ income } & $\$ 3000-\$ 4999$ & $70(35.3 \%)$ & & 5-9 years & $44(22.2 \%)$ \\
\hline & $\$ 5000-\$ 6999$ & $54(27.3 \%)$ & & More than 10 years & $38(19.2 \%)$ \\
\hline & More than $\$ 7000$ & $33(16.7 \%)$ & & & \\
\hline
\end{tabular}

\subsection{Instruments}

A total of 22 items measuring the focal constructs (i.e., brand globalness, perceived value, and customer loyalty) were included in the survey questionnaire. Also, socio-demographic information including gender, age, education level, occupation, monthly income, years of golf experience, and frequency of annual attendance was gathered. All items measuring the latent constructs were borrowed from the well-established existing scales. A 5-point Likert scale, ranging from $1=$ strongly disagree to $5=$ strongly agree, was used for all items. 
We adapted three items to measure brand globalness $(\alpha=0.76)$ from Steenkamp et al. [12]. Functional value $(\alpha=0.85)$ was measured with three items [10]. We used four modified items measuring emotional value $(\alpha=0.89)$ from Sweeney and Soutar [22]. Social value $(\alpha=0.84)$ was measured with two items adapted from Kunkel, Doyle, and Berlin [5]. Altruistic value $(\alpha=0.75)$ was measured with three items adapted from Whang [31]. We adapted two items assessing customer loyalty $(\alpha=0.58)$ from Steenkamp et al. [12].

As the survey items were initially developed in English from the previous studies, we adopted a back-translation method [32]. A bilingual person translated the items into Korean, and then another bilingual individual back-translated them into English. Next, we evaluated whether the translated instruments were clear and accurate. No discrepancies were found.

\section{Results}

\subsection{Descriptive Statistics}

Before examining the hypotheses, we screened the data. The values of skewness $(-1.28$ to -0.58 ) and kurtosis ( -0.32 to 2.51$)$ were found to be well within the cutoff ranges [33]. To check multicollinearity, we examined tolerance ( 0.31 to 0.72 ) and variance inflation factor (1.37 to 3.19), and the results indicated that multicollinearity was not a problem [33]. Table 2 shows descriptive statistics and correlations.

Table 2. Descriptive statistics, correlations of variables, and Cronbach's alpha.

\begin{tabular}{lcccccc}
\hline \multicolumn{1}{c}{ Variables } & $\mathbf{1}$ & $\mathbf{2}$ & $\mathbf{3}$ & $\mathbf{4}$ & $\mathbf{5}$ & $\mathbf{6}$ \\
\hline 1. Brand globalness & 1 & & & & & \\
2. Functional value & $0.22^{* *}$ & 1 & & & & \\
3. Emotional value & $0.34^{* *}$ & 0.03 & 1 & & & \\
4. Social value & $0.19^{* *}$ & $0.25^{* *}$ & $0.21^{* *}$ & 1 & & \\
5. Altruistic value & $0.39^{* *}$ & $0.25^{* *}$ & 0.15 & $0.25^{* *}$ & 1 & \\
6. Customer loyalty & $0.40^{* *}$ & $0.25^{* *}$ & $0.43^{* *}$ & $0.29^{* *}$ & $0.22^{* *}$ & 1 \\
\hline Mean & 4.09 & 4.09 & 4.21 & 4.33 & 3.92 & 4.16 \\
Standard deviation & 0.64 & 0.74 & 0.66 & 0.68 & 0.75 & 0.59 \\
Cronbach's alpha & 0.76 & 0.85 & 0.89 & 0.84 & 0.75 & 0.58 \\
\hline \multicolumn{7}{c}{ Note: } \\
\end{tabular}

\subsection{Measurement Model}

The measurement model was tested via a confirmatory factor analysis (CFA), which indicated an acceptable model fit $\left(\chi^{2} / d f=147.89 / 104=1.42\right.$, comparative fit index [CFI] $=0.97$, root mean square error of approximation [RMSEA] $=0.04$, and standardized root mean square residual [SRMR] $=$ 0.05) [33]. Composite reliability (CR) values ranged from 0.74 to 0.93 , and average variance extracted (AVE) values ranged from 0.58 to 0.84 , demonstrating good convergent validity [34]. All AVE values were higher than the squared correlations of all pairs of constructs, ensuring discriminant validity [34] (see factors loadings in Table 3). 
Table 3. Factor loadings ( $\lambda$ ), composite reliability (CR), and average variance extracted (AVE).

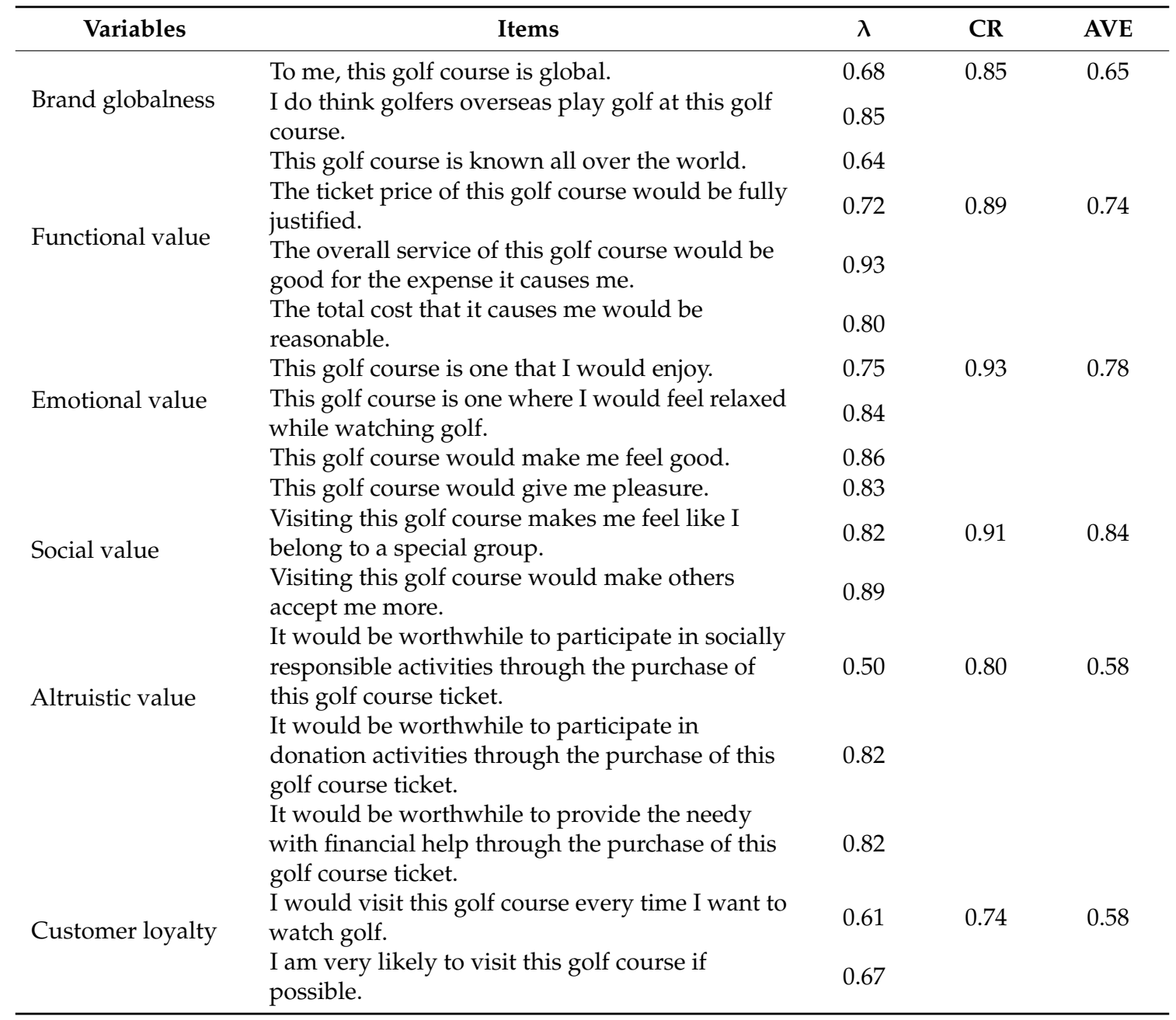

\subsection{Structural Model}

Before testing the hypotheses, a model comparison was conducted with a chi-square difference test. Previous researchers e.g., [35] conceptualized perceived value as a second-order construct. Thus, the proposed model with the first-order multidimensional perceived value constructs was compared with an alternative model with second-order perceived value. The result showed that chi-square difference was statistically significant $\left(\Delta \chi^{2}{ }_{(2)}=10.08, p<0.001\right)$, indicating that the original model was deemed superior to the second-order perceived value model. Therefore, we retained the original model for the hypothesis testing.

The structural model indicated an adequate model fit to the data $\left(\chi^{2} / d f=176.61 / 110=3.15\right.$, $\mathrm{CFI}=0.95$, RMSEA $=0.05$, and SRMR $=0.07)$. The result of SEM showed that brand globalness positively predicted functional value $(\beta=0.31, p<0.01)$, emotional value $(\beta=0.36, p<0.001)$, social value $(\beta=0.32, p<0.01)$, altruistic value $(\beta=0.41, p<0.001)$, and customer loyalty $(\beta=0.27, p<0.01)$. Similarly, functional value $(\beta=0.14, p<0.01)$, emotional value $(\beta=0.34, p<0.001)$, and social value $(\beta=0.12, p<0.05)$ had significant positive effects on customer loyalty. Altruistic value was not significantly related to customer loyalty $(\beta=0.02, p=0.83)$.

We conducted a follow-up analysis to examine the indirect effects of perceived value using a bias-corrected bootstrap based on 5000 resamples [36]. As shown in Table 5, functional $(\beta=0.05$, $p<0.05$, confidence interval $(\mathrm{CI})=0.01$ to 0.16$)$, emotional $(\beta=0.15, p<0.001, \mathrm{CI}=0.07$ to 0.27 ), and social $(\beta=0.07, p<0.05, \mathrm{CI}=0.01$ to 0.21$)$ values significantly mediated the relationship between brand globalness and customer loyalty. The mediating effect of altruistic value was not significant 
$(\beta=-0.02, p=0.74, \mathrm{CI}=-0.20$ to 0.11$)$. The results of the direct and indirect effects are shown in Tables 4 and 5, respectively.

Table 4. The results of hypothesis testing.

\begin{tabular}{llccc}
\hline & Hypothesized Relationships & $\boldsymbol{\beta}$ & $S E$ & Results \\
\hline H1 & Brand globalness $\rightarrow$ Functional value & $0.31^{* *}$ & 0.10 & Supported \\
H2 & Brand globalness $\rightarrow$ Emotional value & $0.36^{* * *}$ & 0.08 & Supported \\
H3 & Brand globalness $\rightarrow$ Social value & $0.32^{* *}$ & 0.10 & Supported \\
H4 & Brand globalness $\rightarrow$ Altruistic value & $0.41^{* * *}$ & 0.09 & Supported \\
H5 & Brand globalness $\rightarrow$ Customer loyalty & $0.27^{* *}$ & 0.10 & Supported \\
H6 & Functional value $\rightarrow$ Customer loyalty & $0.14^{*}$ & 0.06 & Supported \\
H7 & Emotional value $\rightarrow$ Customer loyalty & $0.34^{* * *}$ & 0.08 & Supported \\
H8 & Social value $\rightarrow$ Customer loyalty & $0.12^{*}$ & 0.06 & Supported \\
H9 & Altruistic value $\rightarrow$ Customer loyalty & -0.02 & 0.10 & Not supported \\
\hline \multicolumn{7}{c}{ Note: ${ }^{*} p<0.05 .^{* *} p<0.01 .^{* * *} p<0.001}$. \\
\end{tabular}

Table 5. Indirect effects of perceived value.

\begin{tabular}{|c|c|c|c|c|}
\hline \multirow{2}{*}{ Indirect Effects of Perceived Value } & \multirow{2}{*}{$\beta$} & \multirow{2}{*}{$S E$} & \multicolumn{2}{|c|}{ Bias-Corrected $95 \%$ Confidence Interval } \\
\hline & & & Lower & Upper \\
\hline Functional value & $0.05^{*}$ & 0.04 & 0.01 & 0.16 \\
\hline Emotional value & $0.15^{* * *}$ & 0.05 & 0.07 & 0.27 \\
\hline Social value & $0.07^{*}$ & 0.05 & 0.01 & 0.21 \\
\hline Altruistic value & -0.02 & 0.08 & -0.20 & 0.11 \\
\hline
\end{tabular}

\section{Discussion}

\subsection{Theoretical Contributions}

The present study explored how customers' perceived brand globalness affected multidimensional perceived value, ultimately leading to customer loyalty. We extended the concept of perceived value by incorporating customers' perceived brand globalness, and the results supported the important role of perceived brand globalness and perceived value in predicting customer loyalty in the context of the golf course industry. The findings of the present study revealed that customers' perceived brand globalness of a golf course positively affected customer loyalty through the multiple value dimensions of functional, emotional, and social values. These results are in line with existing brand marketing research $[12,15,19,24,26]$.

Brand globalness and perceived value. The influence of brand globalness on customer loyalty has been widely discussed in the extant literature. For example, Steenkamp et al. [12] and Pyun et al. [26] reported that perceived brand globalness influences perceived value, which in turn affects purchase intention, supporting the findings of this study. Therefore, the more golf customers recognize a golf course's embedded global brand image, the more likely they are to show their purchase intention. Thus, it is plausible that golf customers are likely to recognize the global image of LPGA golf tournaments as a quality assurance signal and show their purchase intention [13].

Perceived value and customer loyalty. The influence of functional value on customer loyalty was found to be significant, which is supported by several previous studies $[11,15,27,37]$. In particular, Swoboda et al. [15] and Roig et al. [11] support the findings of the present study by identifying the relationship between functional value and purchase intention. Thus, the results of our study confirm that functional value is an important driver that promotes customer loyalty toward a golf course brand.

In the current study, we also found that emotional value positively affected customer loyalty. Moliner et al. [27] supported the findings of the present study by stating that package travelers' 
perceived emotional value positively influences customer satisfaction as well as repurchase intention. From the perspective of service marketing, customers' perceived emotional value of enjoyment and excitement derived from their service experiences are perceived as important factors predicting customer satisfaction and customer loyalty, because of the intangible characteristics of services [37]. Thus, the positive influence of golf customers' perceived emotional value on customer loyalty in our research setting can be mainly due to the nature of golf as a leisure sport activity, which is an intangible service characteristic.

Additionally, our findings showed the positive impact of customers' perceived social value on customer loyalty. Researchers $[12,15]$ reported that psychological value, which represents an enhanced social status, has a positive influence on customer loyalty, supporting the findings of the present study. This result of a positive relationship between social value and customer loyalty might have been the case of the specific research setting in the current study. Although the Korean golf population has dramatically increased from 2.75 million in 2007 to 6.19 million in 2014 along with 511 golf courses in $2014[17,38]$, golf is still considered as one of the luxurious leisure sports in Korea not only because of its total costs such as green fees, cart riding, and meals, but also the average time (e.g., four hours) spent to play 18 holes. Thus, it is conceivable that golf customers' high social status perceptions might be an important contributor to creating customer loyalty toward a golf club in our research setting.

However, we found the insignificant influence of altruistic value on customer loyalty, which is inconsistent with previous research [24,39]. Altruistic value, in general, has positive effects on customer loyalty, depending on the brand-cause infinity and individuals' altruistic tendencies, and such effects are greater for an unknown company compared to a well-known one [40]. Moreover, the effects of the altruistic value of a brand linked with a social cause on consumer loyalty can carry over to adjacent brand categories of a firm with multicategory product lines [41]. The accessibility diagnosticity model (ADM) [42] can explain this unexpected finding. The ADM emphasizes two distinctive mechanisms: (a) accessibility, referring to how a customer can easily retrieve a certain piece of information from their memory, and (b) diagnosticity, concerning customers' evaluations of how well the retrieved information can serve as a relevant solution for a given decision-making situation. Applying the ADM theory [42] to the current study, the brand name of a golf course with a global brand image can serve as information with accessibility, but this information cue might not sufficiently be a diagnostic piece of information in creating golf customers' intention to visit the golf course. Although Holt et al. [13] indicate that a favorable response to a global brand is mainly attributable to altruistic value, it is plausible that the brand name of golf courses in our study was not enough diagnostic information for golf customers about customer loyalty. The golf courses in our study have been actively involved in several charity programs such as charity golf tournaments, meal projects for underprivileged children in their communities, and money donation $[43,44]$. Thus, the insignificant effect of golf customers' perceived altruistic value on customer loyalty in the present study can be attributable to the fact that golf customers did not have much information about the charity programs of the golf courses.

\subsection{Practical Implications}

From a managerial standpoint, the findings of the present study suggest that golf course managers should emphasize not only global brand positioning but also golf customers' value perceptions derived from a global brand image. In particular, the competition of the Korean golf course industries has been intensified due to the oversupply of golf courses every year. Instead of focusing on a mere global brand image with an exotic brand name and logo, as is prevalent in the current industry, our study suggests that golf course managers should come up with a slogan that best represents a golf course's global value to achieve its brand globalness. A slogan is one of the most important cues compared to a brand name, logo, or spokesperson in the building of a global brand image, especially in a highly developed market [45].

Furthermore, the findings of our study show that golf course managers can take advantage of golf customers' perceptions of altruistic value associated with brand globalness by providing golf 
customers with diagnostic information. Such sources of information as a corporate social responsibility campaign by collaborating with globally well-known organizations such as UNICEF can provide golf customers with accessible and diagnostic brand information. This might create customer loyalty through enhanced altruistic value perceptions because such a cause might increase the favorable organizational image, which might translate into the local golf course [46].

\subsection{Limitations and Future Directions}

As in any research, several limitations need to be acknowledged. First, because we used cross-sectional data, the results may be subject to endogeneity bias, which typically occurs in the ordinary least squares (OLS) regression model when an independent variable is correlated with the error term, which should be random. This causes a biased estimate of the observed variable [47]. So, caution is required when interpreting the results. As such, we suggest that future scholars replicating our model adopt a lagging independent variable, where a temporal separation among the independent variable (i.e., brand globalness), the mediator (i.e., perceived value), and the dependent variable (i.e., brand loyalty) should be incorporated into the measurement of the variables. Other remedies may include the use of panel data and natural experimental design [47].

Second, the impact of golf customers' perceived altruistic value on customer loyalty was found to be insignificant. As discussed earlier, the finding may be due to the low information accessibility of corporate social responsibility campaigns by golf courses to golf customers in our research setting. Thus, future research might provide written stimuli about charity campaigns of a golf course to better investigate the relationship between golf customers' perceived altruistic value and customer loyalty. Last but not least, the data in the present study were collected from two local golf courses, limiting the generalizability of the findings. As such, we suggest that the tested research model be confirmed with spectators attending different types of golf courses such as the Korean Professional Golf Association (KPGA) tournament sites. This would ensure the external validity of the tested model.

Author Contributions: Conceptualization, W.-y.B.; methodology, W.-y.B., K.A.K., K.K.B., and D.-H.K.; formal analysis, W.-y.B., K.A.K., and K.K.B.; data curation, W.-y.B., K.A.K., and K.K.B.; writing-original draft preparation, W.-y.B.; writing-review and editing, W.-y.B., K.A.K., K.K.B., and D.-H.K.; supervision, K.K.B. All authors have read and agreed to the published version of the manuscript.

Funding: This research received no external funding.

Conflicts of Interest: The authors declare no conflict of interest.

\section{References}

1. Szymanski, D.M.; Henard, D.H. Customer satisfaction: A meta-analysis of the empirical evidence. J. Acad. Mark. Sci. 2001, 29, 16-35. [CrossRef]

2. Fornell, C.; Johnson, M.D.; Anderson, E.W.; Cha, J.; Bryant, B.E. Growing the trust relationship. J. Mark. 1996, 60, 7-18. [CrossRef]

3. Jones, T.O.; Sasser, J.W.E. Why satisfied customers defeat. Harv. Bus. Rev. 1995, 73, 89-99.

4. Byon, K.K.; Zhang, J.J.; Baker, T.A. Impact of core and peripheral service quality on consumption behavior of professional team sport spectators as mediated by perceived value. Eur. Sport Manag. Q. 2013, 13, $232-263$. [CrossRef]

5. Kunkel, T.; Doyle, J.P.; Berlin, A. Consumers' perceived value of sport team games-A multi-dimensional approach. J. Sport Manage. 2017, 31, 80-95. [CrossRef]

6. Jones, C.; Byon, K.; Huang, H. Service Quality, Perceived Value, and Fan Engagement: Case of Shanghai Formula One Racing. Sport Mark. Q. 2019, 28, 63-76. [CrossRef]

7. Hu, H.-H.; Kandampully, J.; Juwaheer, T.D. Relationships and impacts of service quality, perceived value, customer satisfaction, and image: An empirical study. Serv. Ind. J. 2009, 29, 111-125. [CrossRef]

8. Drayer, J.; Shapiro, S.L.; Dwyer, B. Worth the price of admission? The mediating effect of perceived value on ticket purchase intention. Sport Mark. Q. 2018, 27, 44-57. 
9. Kim, K.; Byon, K.K.; Baek, W. Customer-to-customer value co-creation and co-destruction in sporting events. Serv. Ind. J. 2019, 1-23. [CrossRef]

10. Steenkamp, J.E.B.M.; Geyskens, I. What drives the perceived value of web sites? A cross-national investigation. J. Mark. 2006, 70, 136-150. [CrossRef]

11. Roig, J.C.F.; García, J.S.; Tena, M.; Ángel, M. Perceived value and customer loyalty in financial services. Serv. Ind. J. 2009, 29, 775-789. [CrossRef]

12. Steenkamp, J.E.B.M.; Batra, R.; Alden, D.L. How perceived brand globalness creates brand value. J. Int. Bus. Stud. 2003, 34, 53-66. [CrossRef]

13. Holt, D.B.; Quelch, J.A.; Taylor, E.L. How global brands compete. Harv. Bus. Rev. 2004, 82, 68-75. [PubMed]

14. Zhou, L.; Yang, Z.; Hui, K.M. Non-local or local brands? A multi-level investigation into confidence in brand origin identification and its strategic implications. J. Acad. Mark. Sci. 2010, 38, 202-218. [CrossRef]

15. Swoboda, B.; Pennemann, K.; Taube, M. The Effects of Perceived Brand Globalness and Perceived Brand Localness in China: Empirical Evidence on Western, Asian, and Domestic Retailers. J. Int. Mark. 2012, 20, 72-95. [CrossRef]

16. Harrington, R. Golf Directly Drove $\$ 84.1$ Billion (yes with a 'B') in U.S. Economic Activity, According to New Study. Available online: https:/www.golfdigest.com/story/golf-directly-drove-dollar-84-billion-in-useconomic-activity-according-to-new-world-golf-foundation-study (accessed on 26 October 2019).

17. Korean Ministry of Culture and Tourism. 2016 Sport Industry White Paper; Korean Ministry of Culture and Tourism: Seoul, Korea, 2017.

18. Alden, D.L.; Steenkamp, J.B.; Batra, R. Brand positioning through advertising in Asia, North America and Europe: The role of global consumer culture. J. Mark. 1999, 63, 75-87. [CrossRef]

19. Davvetas, V.; Sichtmann, C.; Diamantopoulos, A. The impact of perceived brand globalness on consumers' willingness to pay. Int. J. Res. Mark. 2015, 32, 431-434. [CrossRef]

20. Zeithaml, V.A. Consumer perceptions of price, quality, and value: A means-end model and synthesis of evidence. J. Mark. 1988, 52, 2-22. [CrossRef]

21. Sanchez, J.; Callarisa, L.; Rodríguez, R.M.; Moliner, M.A. Perceived value of the purchase of a tourism product. Tour. Manag. 2006, 27, 394-409. [CrossRef]

22. Sweeney, J.C.; Soutar, G.N. Consumer perceived value: The development of a multiple item scale. J. Retail. 2001, 77, 203-220. [CrossRef]

23. Holbrook, M.B. Consumption experience, customer value, and subjective personal introspection: An illustrative photographic essay. J. Bus. Res. 2006, 59, 714-725. [CrossRef]

24. Baek, W.Y.; Byon, K.K.; Choi, Y.H.; Park, C.W. Millennial consumers' perception of sportswear brand globalness impacts purchase intention on cause-related marketing. J. Soc. Behav. Pers. 2017, 45, 1319-1336. [CrossRef]

25. Dick, A.S.; Basu, K. Customer loyalty: Toward and integrated conceptual framework. J. Acad. Mark. Sci. 1994, 22, 99-113. [CrossRef]

26. Pyun, D.Y.; Kwon, H.H.; Lee, C.-W. The influences of perceived brand quality and ethnocentrism on consumption patterns of a global sports brand: the case of Korean college students. Int. J. Sports Mark. Spons. 2011, 13, 18-32. [CrossRef]

27. Moliner, M.A.; Sanchez, J.; Rodriguez, R.M.; Callarisa, L. Relationship quality with a travel agency: The influence of the post-purchase perceived value of a tourism package. Adv. Cult. Tour. Hosp. Res. 2007, 7, 194-211. [CrossRef]

28. Kim, K.; Byon, K.K.; Baek, W.; Williams, A.S. Examining structural relationships among sport service environments, excitement, consumer-to-consumer interaction, and consumer citizenship behaviors. Int. J. Hosp. Manag. 2019, 82, 318-325. [CrossRef]

29. Sirak, R.; Waraksa, M. Making Big Bucks, Spending Big Bucks. Available online: https://www.golfdigest. com/story/the-masters-finances-ron-sirak (accessed on 26 October 2019).

30. Whitten, R.; Hennessey, S. Golf Digest's Complete 200 Greatest International Golf Courses. Available online: https://www.golfdigest.com/story/golf-digests-international-greatest-golf-courses (accessed on 26 October 2019).

31. Whang, M. Developing a model on the effects of perceived value on post consumption outcomes: A new insight into altruistic value. J. Consum. Policy 2014, 4, 1-23.

32. Brislin, R.W. Back-Translation for Cross-Cultural Research. J. Cross-Cult. Psychol. 1970, 1, 185-216. [CrossRef] 
33. Hair, J.F.; Black, W.C.; Babin, B.J.; Anderson, R.E. Multivariate Data Analysis, 7th ed.; Prentice Hall: Upper Saddle River, NJ, USA, 2010.

34. Fornell, C.; Larcker, D. Evaluating structural equation models with unobservable variables and measurement error. J. Mark. Res. 1981, 18, 39-50. [CrossRef]

35. Fiol, L.J.C.; Tena, M.A.M.; Garcia, J.S. Multidimensional perspective of perceived value in industrial clusters. J. Bus. Ind. Mark. 2011, 26, 132-145. [CrossRef]

36. Preacher, K.J.; Hayes, A.F. Asymptotic and resampling strategies for assessing and comparing indirect effects in multiple mediator models. Behav. Res. Methods 2008, 40, 879-891. [CrossRef]

37. Yang, Y.; Liu, X.; Jing, F.; Li, J. How Does Perceived Value Affect Travelers' Satisfaction and Loyalty? Soc. Behav. Pers. Int. J. 2014, 42, 1733-1744. [CrossRef]

38. Korea Golf Association. 2014 Korean Golf Index; Korea Golf Association: Seoul, Korea, 2014.

39. Yadav, R. Altruistic or egoistic: Which value promotes organic food consumption among young consumers? A study in the context of a developing nation. J. Retail. Consum. Serv. 2016, 33, 92-97. [CrossRef]

40. Henderson, T.; Arora, N. Doing Well While Doing Good. Linking A Social Cause To Product Promotions: Why It Works And How To Make It More Effective. GfK Mark. Intell. Rev. 2010, 2, 8-15. [CrossRef]

41. Henderson, T.; Arora, N. Promoting Brands across Categories with a Social Cause: Implementing Effective Embedded Premium Programs. J. Mark. 2010, 74, 41-60. [CrossRef]

42. Feldman, J.M.; Lynch, J.G. Self-generated validity and other effects of measurement on belief, attitude, intention and behavior. J. Appl. Psychol. 1988, 73, 421-435. [CrossRef]

43. Jack Nicklaus Golf Club Korea. Introduction of Jack Nicklaus Golf Club Korea. Available online: https: //www.jacknicklausgolfclubkorea.com/pages/about/overview.asp (accessed on 2 November 2019).

44. SKY72 Golf \& Resort. Introduction of SKY72 Golf Course. Available online: http://www.sky72.com/kr/info/ csr0301.jsp2018 (accessed on 2 November 2019).

45. De Meulenaer, S.; Dens, N.; De Pelsmacker, P. Which cues cause consumers to perceive brands as more global? A conjoint analysis. Int. Mark. Rev. 2015, 32, 606-626. [CrossRef]

46. Gwinner, K.P.; Eaton, J. Building Brand Image Through Event Sponsorship: The Role of Image Transfer. J. Advert. 1999, 28, 47-57. [CrossRef]

47. Zaefarian, G.; Kadile, V.; Henneberg, S.C.; Leischnig, A. Endogeneity bias in marketing research: Problem, causes and remedies. Ind. Mark. Manag. 2017, 65, 39-46. [CrossRef] 